\title{
Poverty and Socioeconomic Injustice in Muslim Geographies
}

BigeSaatçioğlu, Özlem Sandıkcı and Aliakbar Jafari

\section{Introduction}

Muslims are among the poorest of the poor in the world. Around $40 \%$ of the Muslim population languishes in abject poverty, with nearly 350 million living under US\$1.25 a day (COMCEC, 2014). More than half of the world's 57 Muslim countries are listed as lowincome food deficit countries by the Food and Agriculture Organization of the United Nations (FAO 2014) and almost half of them ranks in the low category in the United Nations Development Program's Human Development Index (UNDP, 2014). Nearly 30\% of Muslims cannot read or write; in tribal rural areas, female illiteracy rate can go up to $75 \%$ (SESRIC 2013). Overall, Muslims constitute around $24 \%$ of the world population yet produce only $10 \%$ of the global GDP (SESRIC, 2012) and exhibit a poor performance on most of the key development indicators.

Despite these bleak statistics and their obvious implications for marketing and macromarketing scholarships, the newly emergent field of Islamic Marketing remains silent on the issues of poverty, wellbeing, and socioeconomic injustice. The interest in Islamic marketing is largely driven by an image of Muslims as a marginalized and untapped consumer segment waiting to be served by international companies (for a critical review, see Sandıkc1, 2011, Jafari, 2012; Jafari and Sand1kc1, 2015). Accordingly, much of the existing research focuses on the relatively wealthy, educated, and urban Muslim consumers and their consumption practices (for an exception, Izberk-Bilgin, 2011). While there is much value in 
this body of work, we believe that the current conditions of Muslim populations warrant critical research attention on the intersections of marketing, justice, and development. While there are extremely rich Muslim consumers, a significant portion of Muslims live under conditions of poverty, vulnerability, and social and economic inequality. Our goal in this chapter is to call marketing scholars' attention to the poor Muslim consumers and offer a critical research agenda to explore the nature and ramifications of poverty and socioeconomic injustice in the Muslim marketspaces.

We begin the chapter with an overview of the marketing scholarship on poverty. Our review summarizes different conceptualizations and causes of poverty and outlines coping strategies and poverty alleviation mechanisms identified in the literature. We then look into how socioeconomic justice is conceptualized in the Islamic texts and discuss how these conceptualizations inform Islamic approaches to the challenge of poverty. In particular, we discuss different interpretations of poverty in the Islamic texts and outline the key poverty alleviation instrument, zakat (obligatory almsgiving). In the final section of the chapter, we offer a critical research agenda to further our understanding of how markets are/can be implicated in the production, reproduction, and eradication of poverty and socioeconomic injustice in Muslim geographies. Among potential study topics we discuss are understanding the tensions and contradictions between theological definitions and lived experiences of poverty, the gender dynamics implicated in the nature and experiences of socioeconomic inequality, the role of Islamic movements and faith organizations in poverty alleviation, and the marketplace actors shaping the discourses on socioeconomic justice and injustice.

\section{Marketing Scholarship on Poverty}


Poverty has been conceptualized, measured, and studied in many different ways across a range of disciplines such as economics, sociology, psychology, and consumer research. In this section, we first review different approaches to poverty while paying attention to similarities and differences across various frameworks. Then, we discuss recently emerging and more holistic frameworks that investigate poverty as a multi-faceted phenomenon. We conclude with a discussion on the multiple ways of coping with poverty and how different stakeholders (e.g., corporations, policy makers, non-profit organizations) can help improve the conditions and processes that lead to impoverishment.

\section{Conceptualizations of Poverty}

Absolute vs. Relative Views. Perhaps the oldest and most traditional conceptualization of poverty is formulated around the theoretical debate between two camps: the absolute view and the relative view (for an overview, see Lister, 2004). According to the absolute view, impoverishment concerns the lack of material resources that are necessary for living a minimally decent life. The poor suffer from deprivation because they lack sufficient economic capital to meet their most basic needs such as shelter, nutrition, and clothing. The absolute perspective advocates for a threshold level to measure poverty in terms of income level and other sources of material wealth (Jones and Novak, 1999; Lister, 2004). As such, this approach has been criticized as a one-dimensional perspective that largely excludes the impact of multiple co-existing forms of deprivation that arise from a lack of socially necessary items beyond mere income (e.g., child care, transportation, recreation). However, while one-sided and incomplete, the absolute view helps focus on the most basic dynamics of survival that is at the center of various forms of deprivation. 
In contrast, the relative view adopts a more holistic angle and goes beyond mere income to examine poverty as a multi-faceted condition with economic, social, cultural, and political ramifications (Jordan, 1996; O’Connor, 2001). When consumers lack basic necessities, they are not only deprived of material wealth but also excluded from the educational domain, workforce, and communal life (Townsend, 1993). From a consumer research perspective, relative deprivation is a condition in which people do not have access to socially necessary items and resources that would fit with the standards of the contemporary marketplace. In consumer research, Hill (2002, p. 20) defines consumption adequacy as "the continuous availability of a bundle of goods and services that are necessary for survival as well as the attainment of basic dignity and self-determination." Under this view, the measurement of poverty based on an income-based threshold level becomes problematic. Instead, scholars who adopt the relative approach argue that "if income is not the sum of human development, then lack of it cannot be the sum of human deprivation" (Malhotra, 2004, p. 15).

Although advocating a more holistic take on poverty, the relative approach has been able to escape criticism. For instance, Lister (2004) suggests that the notion of relative deprivation is context-specific and hence, can be misleading when applied in a geographical setting where the majority of the population can barely survive (e.g., India, Bangladesh and Africa). In such largely resource-deprived communities, proponents of the relative view might only consider those at the very bottom of the socioeconomic ladder as 'poor' and exclude other impoverished people when designing necessary interventions. Similarly, if researchers were to apply the central premise of the relative approach-"the lack of socially perceived necessities" (Bradshaw and Finch, 2003, p. 515) in a society where living standards are relatively higher (e.g., the U.S.A. and Switzerland), they might classify those people at the 
bottom of the socioeconomic ladder as poor. Hence, this classification would be misleading when compared to other contexts and resource-poor geographies.

Despite their differences, the absolute and relative views are not mutually exclusive; rather, they complement each other. A person who is financially impoverished would naturally be excluded from the sociocultural and political domain. However, when taken together, conceptualization and measurement of poverty across the two approaches still suggest a dichotomy that privileges material/financial or socialcultural dynamics. In response to this dialectical tension, more recent conceptualizations of poverty have tried to bridge the two paradigms and focused on such concepts as 'social exclusion,' 'capability deprivation,' and 'felt deprivation' (Sen, 1999, 2000; Blocker et al., 2013) to capture the multi-faceted nature of poverty.

Recent Approaches to Poverty. Emerging frameworks on poverty involve a consideration of multiple, co-existing disadvantages that constitute the lived experience of the poor. The definition of poverty now goes beyond mere income and any other financial resources and includes intersecting disadvantages. Increasingly, researchers have equated poverty with such terms as 'capability deprivation' (Sen, 1999), 'social exclusion' (Room, 1999; Sen, 2000), 'felt deprivation' (Blocker et al., 2013), and 'relational disadvantage' (Waxman, 1983). In consumer research, Chakravarti (2006) offers a psychological perspective and examines the psychological impacts of deprivation on motivation, perception, and cognition. Taking an anthropological view, Narayan (2000) highlights the material, social, cultural, and experiential aspects of impoverishment and conceptualizes poverty as 'ill-being.' Another research stream illustrates the social aspects of poor living; O'Brien et al. (2009, p. 3) define 
poverty as "a rupture of social bonds" and similarly, Sen (2000) suggests that poverty means social exclusion as poor individuals and communities are increasingly being excluded from many domains. For instance, being excluded from the workforce due to a lack of employment opportunities leads to economic impoverishment that in turn might result in other deprivations such as lack of balanced nutrition, adequate housing, and education. In his conceptualization of social exclusion, Sen (2000) also distinguishes between "constitutive relevance of social exclusion" vs. "instrumental relevance of social exclusion" (p. 13). Social exclusion is constitutively relevant if it represents a loss on its own that directly impoverishes consumers' lives in addition to the other indirect deprivations it might cause (e.g., lack of access to health care). On the other hand, there are cases for instrumentally relevant forms of social exclusion whereby relational forms of deprivations can only indirectly lead to further deprivations such as lack of access to the credit market leading to 'income poverty.'

Overall, despite differences in various approaches, one commonality exists: poverty is a dynamic, multidimensional, and experiential condition that varies from context to context and across cultures. In addition, recent approaches to poverty involve a more critical angle with attention to the role of multiple social actors (e.g., the poor, corporations, government bodies, and various institutions) in causing, exacerbating, or alleviating poor living conditions.

\section{Sources of Poverty}

Echoing the division between the absolute and relative views, a dichotomous understanding of the causes of poverty characterizes much of the literature: the individual (or cultural) perspective and the structural perspective. Also known as the 'welfare culture,' or 'blaming the victim' approach, the individual view argues that poor people are responsible for their 
impoverishment and poverty is a condition that is passed on through generations. Rooted in American anthropologist Oscar Lewis' $(1959,1970)$ thesis, the individual approach views the poor as a dysfunctional, deviant, and generational subculture with its own worldview and consumption habits. The characteristics of the poor include, but are not limited to, "strong feelings of marginality, helplessness, dependence, and inferiority...weak ego structure, confusion of sexual identification, a lack of impulse control,... and a high tolerance for psychological pathology of all sorts" (Lewis 1970, p. 73). Hence, poor living conditions are viewed as the natural consequences of the impoverished people's behaviour and lifestyles. The culture of poverty thesis is consistent with the moralistic underclass discourse (MUD) that is highly criticized in the social exclusion paradigm (Levitas, 1998). Like the culture of poverty, MUD emphasizes individual behaviours and ways of life in explaining poverty and portrays the poor as having no morals. In addition, it perpetuates social stigmas and categorization of the poor as living in a 'dependency culture' or 'underclass.'

In contrast with the individual perspective, the structural argument highlights the role of macro-level dynamics and processes in causing and exacerbating poverty (Rank, 2004; Newman and Chen, 2007). Challenging the cultural perspective that largely attributes poverty to individual deficiencies, the structural approach focuses on external dynamics (e.g., unemployment, lack of affordable housing, racial and geographical segregation, inadequate healthcare, and gender discrimination). The notion of 'structural vulnerability' is at the core of this approach and researchers who follow this tradition argue that poverty leads to cultural and social exclusion. Compared with the previous framework, structural approach takes a more humanistic angle and aims at untangling the dynamics underlying macro forces rather than attributing poor living conditions to individual and cultural characteristics. 
With some notable exceptions (e.g., Hill and Stamey, 1990; Hill, 1991; Ustuner and Holt, 2007), extant consumer research on poor populations is inspired by the structural view. Consumer researchers have explored various unfair marketplace conditions such as fewer product and service offerings in geographically and racially segregated areas (Andreasen, 1975; Crockett and Wallendorf , 2004), unjust sales practices and higher prices (Alwitt, 1995; Alwitt and Donley, 1996), and financial obstacles such as lack of access to credit and banking (Andreasen 1993, 1997). Recently, more pragmatic and policy-oriented approaches have been advocated by social scientists and consumer researchers to help overcome these structural challenges (see the section on Poverty Alleviation).

\section{Coping with Poverty}

In dealing with financial, psychological, and socio-cultural hardships, impoverished individuals and disadvantaged communities engage in different forms and levels of agency. While some coping strategies are merely geared towards survival and getting by, others are planned to resist oppressive macro-level processes and structural forces (i.e., welfare system, healthcare, and social stigmatization). Below, we discuss three main types of coping tactics utilized by the poor.

Individual Acts of Survival. Grounded mostly in economics and psychology literatures, this form of coping reflects the need to survive and get-by in the marketplace. As "an active process of juggling, piecing together, and going without," (Lister, 2004, p. 133), survival strategies help poor consumers manage economic, emotional, and social challenges. When relying on acts of survival, the poor's main goal is to "make space or creating room for 
maneuver within constraints" (Gilliat, 2001, p.139). In his work on the adaptation strategies of the impoverished people to the contemporary marketplace, Stephen Gilliat (2001) discusses two types of financial coping tactics used by the poor: minimizing expenditures (e.g., budgeting, cutting back on one's expenses, and consuming second-hand goods) and augmenting existing resources (e.g., borrowing from other people, and self-provisioning). Although these financial measures sound simplistic and straightforward, the poor can get creative in their struggle for material subsistence. For example, Saatcioglu and Ozanne (2013) discuss how residents of a mobile home park exercise their creativity in decorating their home and make curtains out of trash bags. Likewise, Hill and Stamey's (1990) homeless informants engage in recycling and scavenging to secure basic needs.

Acts of survival are not limited to simply managing material and financial resources. Various psycho-social tactics are utilized by the poor to deal with emotional and social challenges. Finding comfort in 'sin products' such as tobacco and alcohol (Gilliat, 2001), relying on social networks (Hill, 2001), and engaging in emotional tactics such as denial, avoidance, fantasizing (Miller and Kaiser, 2001) are among such tactics.

Individual Acts of Defiance. This type of coping involves defiant and disruptive practices in order to 'get back at' (Gilliom, 2001; Lister, 2004) a system perceived to be unfair and oppressive. Despite the significant attention it receives in social sciences (Scott, 1985, 1990; Wagner, 1993), this is perhaps the least examined form of coping in consumer research. Yet this stream of research offers considerable potential in exploring different social constructions of poverty. 
Grounded in the literature on power, resistance, and agency (Foucault, 1978; Scott, 1985, 1990), acts of defiance can be examined under two categories. First, there are subtle, symbolic, and reactive acts that have a therapeutic function as they reflect "a form of individual self-help” (Scott, 1985, p.29). Referred to as 'everyday forms of resistance' (Scott, 1985), these are routine strategies aimed at countering the oppressive nature of the system. In his seminal work on poor Malay peasants, political scientist James Scott (1985, p. 36) discusses various types of such strategies as "foot dragging, dissimulation, false compliance, pilfering, feigned ignorance, slander, arson, sabotage, and so forth.” An example of such subtle and symbolic coping behaviour is provided by Adkins and Ozanne (2005) in consumer research. In this study, low-income people who lack proper literacy skills engage in flirtation and deception when managing stigmatizing marketplace encounters within the healthcare arena. Other examples of symbolic defiant practices of the poor are targeted at countering social stigmatization and degrading discourses. For instance, some working-poor employed within service industries have been documented waiting for daytime employment rather than working on night shifts to feel like a 'normal' employee, refusing to wait on rude customers, providing fake immigration documents to secure jobs, and even 'shopping' by eating off the supermarket shelves (Paules, 1991; Shipler, 2004). Once again, these acts are not collectively organized movements challenging the system but rather personal and localized micropolitical acts of everyday life (Murray and Ozanne, 2006).

Organized and Collective Acts of Coping. On a more proactive level, poor communities get mobilized and engage in organized community action to cope with unfair living conditions. Impoverished families and communities starting out their home-based businesses with the help of micro-credit opportunities in 'subsistence marketplaces' such as Bangladesh and 
India (Viswanathanand Rosa, 2007, 2010; Prahalad and Hammond, 2002) are one notable example of collectively managing poor living. Close-knit social networks and entrepreneurial opportunities offered to subsistence consumers constitute a key characteristic of these communities that have taken major steps toward poverty alleviation.

Other times, poor communities raise their voice against what they perceive to be an oppressive and unfair system. Some classic examples of this type of community action is the case of Appalachian coal miners protesting poor working conditions (Gaventa, 1980), the Living Wage Movement in the U.S.A. (Luce, 2004), and, at a smaller scale, the case of one mobile home park residents protesting the local government's zoning plans to close down the park (Saatcioglu and Ozanne, 2013).

\section{Poverty Alleviation}

Consumption encompasses a multitude of economic, social, and cultural dimensions and is intended to achieve diverse purposes. Recent work in consumer research, sociology, and behavioural economics suggest that consumption choices and habits of the poor reflect neither the rational and goal-oriented behaviours of the affluent populations (Chakravarti, 2006) nor a deviant 'culture of poverty' (Lewis, 1959) gathered around poor choices and misguided behaviours. Instead, poor consumers demonstrate "basic weaknesses and biases that are similar to those of people from other walks of life, except that in poverty, there are narrow margins for error, and the same behaviours often manifest themselves in more pronounced ways and can lead to worse outcomes" (Bertrand, Mullainathan, and Shafir, 2006, p. 8). Hence, efforts to alleviate financial and sociocultural deprivation necessitate a deeper understanding of the poor's surrounding circumstances and conditions. Action 
research driven and participatory methods (e.g., visual techniques, ethnography, participatory drama, social mapping, and PhotoVoice) are useful to untangle the complex, lived experiences of the poor (Ozanne and Saatcioglu, 2008). A significant example of such participatory approach is the three-volume ethnographic study of the World Bank's The Voices of the Poor: Crying Out For Change (2000). This work encompasses fieldwork conducted in 60 countries and involves the participation of more than 60,000 impoverished people.

Yet, uncovering poor consumers' realities is not sufficient to overcome deprivations. A more inclusive approach that requires the involvement of multiple stakeholders (e.g., consumers, corporations, government organizations, charities, and non-profits) is needed to understand how poverty is socially constructed and how it can be alleviated. Such large-scale, multiparty efforts towards poverty alleviation have been initiated and conducted by international organizations such as the World Bank (Talukdar, Gulyani, and Salmen, 2005) and the United Nations (Schultz et al., 2012). On a more localized level, both formal and informal microenterprise opportunities made available to poor consumers in subsistence (or 'bottom-of-thepyramid') marketplaces help them participate in the marketing system not only as consumers but also as producers of goods and services (Viswanathan, Rosa, and Ruth, 2010; Viswanathan, Sridharan and Ritchie, 2010). One distinguishing characteristic of these microenterprises is the existence of closely knit social networks (e.g., subsistence consumers, communal organizations, firms, NGOs, and other supporting entities such as Grameen Bank) working together for the alleviation of poor living. 
Similarly, other notable and emerging approaches advocated by marketing and consumer researchers include the advocacy for integrative justice models (Santos and Laczniak, 2009), the need for decentralized policies and welfare programmes (Bertrand, Mullainathan, and Shafir, 2006), constructive stakeholder engagement with a focus on macromarketing (Shultz, 2007), and participatory action research oriented programmes (Ozanne and Saatcioglu, 2008; Ozanne and Anderson, 2010). The recent shift towards a more pragmatic and policy-oriented take on poverty is also evident in the Transformative Consumer Research (TCR) initiative which has set its goals as improving individual and societal well-being, engaging institutions, and encouraging civic empowerment (Mick, Pettigrew, Pechmann, and Ozanne, 2011).

\section{Islamic Conceptualizations of Justice and Poverty}

As any religious text, the Koran and hadiths are open to a variety of interpretations. This inevitable diversity underscores the complexities when labelling something as 'Islamic.' Hence, our review of Islamic conceptualizations of justice and poverty should be read as statements based on some well-established interpretations of Islam. Keeping this caution in mind, we observe that there is a widespread consensus on the central place Islam accords to justice. The objective of justice stands next in order of priority to the belief in the oneness of Allah and the truth of the Prophethood of Muhammad (Ahmad and Hassan, 2000). From the Islamic perspective, injustice is seen as "equivalent to 'absolute darkness' because injustice undermines solidarity, accentuates conflict and tensions, and aggravates human problems (Chapra, 2011, p.3).

Islam identifies two general principles to achieve justice in society: the principle of social balance and the principle of general mutual responsibility (Kuran, 1989; Okte, 2010; Ahmad 
and Hassan, 2000). Islam values prosperity and happiness and advises the believers to enjoy the worldly bounties. However, it discourages extravagance and ostentation, and forbids gross inequalities; if some people live in luxury while the great majority suffers from misery, hunger, and poverty, that society cannot be considered properly Islamic. Islam also requires fairness in the economic system in which individuals are responsible for their gains as well losses. Overall, Islam tolerates economic inequalities as long as the rich gain wealth fairly, act in moderation, and engage in charitable giving.

Islam recognizes that, given natural differences in human potential, some members of the society will be poorer than others. However, there is no unanimously agreed upon definition of poverty, and different schools of jurisprudence offer divergent conceptualizations (Kroessin, 2011). The Koran mentions two main categories of disenfranchised people, the poor (faqr) and the needy (maskanah), and states that both groups are eligible to receive Islamic charities (Koran, 9:60). Scholars interpret these groups as referring to varying degrees of poverty. The poor are generally considered to be those who have some income but are not able to satisfy all their needs; whereas, the needy are those who completely lack the means to satisfy their basic needs (Qardawi, 1999; Al Khayyat, 1993). In regard to the question of what constitutes basic needs, Islamic resources do not provide a fixed list of goods and services. Among the suggested items are food, clothing, shelter, education, medical care and even a spouse; yet, the content of the list can vary according to the traditions of a society (Sadeq, 1997).

In addition to the poor and the needy, there are other categories of people who need temporary or permanent monetary assistance (Ahmad and Mohamad, 2012). First is the 
overburdened (al-gharimun). These include people overwhelmed by debts incurred in good faith, for consumption or business needs, and those who have lost their properties due to natural disasters. Then, there is the wayfarer ( $i b n$ al-sabil), a person who is far from home, facing hardship and unable to return. People who are subject to racial or religious persecution, political exiles, and refuges are among the wayfarers of the contemporary world (UlHaq, 1996). And, there are people who can satisfy their basic needs and have a surplus less than zakat nisab (Sadeq, 1997). The zakat nisab is a minimum amount of wealth which makes payment of zakat obligatory. Anybody below nisab is eligible to receive zakat, hence regarded as a poor person even though he/she is economically better off than 'the poor' and 'the needy'.

Along with meanings, causes of poverty vary. In line with the social science and marketing approaches, Islamic perspective acknowledges individual and structural causes of poverty (Farooq, 2008; Kroessin, 2011). Unemployment, loss of spouse, divorce, natural disasters, medical conditions, physical disabilities, and other forms of individual hardships may lead to poverty. On the other hand, the pervasive, chronic, and deep-seated destitution of the Muslim world is often viewed as a legacy of the western hegemony (for a review, see Kuran, 1997). Islamic discourses tend to depict a romanticized account of the early days of Islam and claim that there was no poverty under the early caliphs' rule (Khan, 1989). Locating the root of the poverty problem at external structures (e.g., colonialism, capitalism, and feudalism), this account advocates a return to the golden days of Islam and a rigorous application of zakat as the main wealth redistribution system. However, as Farooq (2008) argues, even if the romanticized impressions were true, zakat and other forms of Islamic charities might be 
suitable for helping the incidental poor but fall short in solving the problem of structural poverty in today's world (see also Kuran, 1989).

Nevertheless, in the Islamic approaches to poverty alleviation zakat constitutes the primary means (Nienhaus, 2006; Metwally, 1997). Zakat is one of the five pillars of Islam and is an obligatory form of almsgiving that requires the rich to give a certain percentage of their wealth to eligible members of society. According to the Koran, zakat is given for "the poor and the needy, and for those employed to collect [zakat] and for bringing hearts together and for freeing captives and for those in debt and in the way of Allah and for the traveller" (Koran, 9:60). Muslim scholars point out that zakat is not only the duty of those with disposable wealth but it is the right of those in need (Dean and Khan, 1997). Since eligible recipients of zakat include categories of people other than the economically disadvantaged, zakat functions not only as a wealth redistribution system but a method for purifying the self (Benthall, 1999; Bonner, 2005; Farooq, 2008). That is, "by giving up a portion of one's wealth, one purifies that portion which remains, and also oneself, through a restraint on one's greed and imperviousness to others' sufferings. The recipient, likewise, is purified from jealousy and hatred of the well-off" (Benthall, 1999, p.29). However, some scholars argue that the emphasis on the purification of wealth has limited the potential of zakat for achieving redistributive justice (Farooq, 2008; Kuran 1989). That is, rather than evolving to be a systematic instrument for alleviating and eradicating poverty, zakat has come to assume a more palliative role in society.

Overall, Islam places a fundamental role on social justice and identifies a number of vehicles for redistributing wealth from the haves to the have-nots. Although extreme inequalities are 
not tolerated, interpersonal differences in income are accepted. Zakat operates as the primary poverty alleviation instrument even though there are serious debates about its nature and potential effects. However, despite the emphasis on socioeconomic justice in both the religious texts and the Islamic economics literature, poverty continues to be an endemic problem in much of the Muslim geography. In the next section, drawing upon the extant work in marketing, Islamic economics and the broader social science disciplines, we identify a number of research areas that require critical attention. Studies on these areas can provide further insights into the experiences, dynamics, and implications of poverty in the Muslim marketplaces and enrich the scholarship on poverty and socioeconomic injustice in the general field of marketing.

\section{A Critical Research Agenda}

We organize our discussion into two main domains of research: 1) lived experiences of poverty; 2) Islamic charities, power dynamics, and poverty alleviation. In pursuing these areas, we advocate a multidisciplinary and critically-informed research approach that is sensitive to the complex and intertwined realities of the contemporary world and the dynamics of religion in the new political economy. As many scholars contend, in contrast with the expectations of the secularization theory, religion has become even more prominent and visible across the world (e.g., Wilson and Steger, 2013) and new forms of religio-ethnoeconomic practices embedded within the logic of neoliberal capitalism have emerged (e.g., Gauthier, Martikainen and Woodhead, 2013). Such visibility and diversity offer opportunities for both micro and macro level analyses on the intersections of religion, poverty, and marketplace and hold significant potential for advancing theory. 


\section{Lived Experiences of Poverty}

There is a clear lack of an understanding of the lived experiences of the poor Muslim consumers. While there is relatively little research on Islam-consumption intersection in marketing in general, there are very few studies that explore how Islam shapes (and is shaped by) everyday practices of disenfranchised Muslim consumers (e.g., Izberk-Bilgin, 2011).

Studies within the Islamic economics field, on the other hand, mostly adopt a theological view of poverty and employ the categories identified in the Koran, the poor and the needy, in their analyses. Apart from the ambiguities regarding this categorization, how these normative definitions correspond to the lived reality of life remains unknown. Accordingly, research that looks into how poor Muslim consumers construct their identities and experience their everyday lives can offer new insights into the tensions, contradictions, and negotiations between religious definitions and everyday experiences of poverty. Several consumer research opportunities emerge out of the domain of the lived experience.

First, research is needed to understand if and how the concepts of absolute and relative poverty resonate in daily lives of impoverished Muslim consumers. As we discussed, there is no consensus on what constitutes basic needs from the Islamic perspective. Contextually and temporally sensitive studies can shed light on the discursive construction of needs and the role of market actors in this process. Scholars can also look at how and with what effects poor Muslim consumers are able to negotiate their needs in the marketplace. Furthermore, the distinction in the Koran between material and spiritual poverty raises interesting questions. While material poverty is concerned with the need of tangible resources such as food and shelter, spiritual poverty is about the need of anything or anyone except Allah (Guner, 2005). Islam encourages spiritual poverty (i.e., awareness of one's dependence on God) but not 
material poverty (see also Jafari and Süerdem, 2012). Studies can explore how material and spiritual conceptualizations of poverty interact with each other and inform the meanings, feelings, and experiences of being poor in Muslim contexts. Furthermore, as discussed previously, exploring the dynamics of individual vs. structural perspectives on poverty can shed light on how impoverishment is constructed in multiple ways within Muslim contexts.

Second, research is needed to understand the individual and collective coping strategies utilized by poor Muslim consumers and assess the role of faith in surviving in the marketplace. According to the religion as buffer thesis, religion might ease the negative life circumstances including poverty (Gebauer, Nehrlich, Sedikides and Neberich, 2012) and injustice (Joshanloo and Weijers, 2015). In this view, religion is seen as capable of inspiring a belief that no matter how bad life might be, there is an underlying higher, God-given reason (Hackney and Sanders, 2003). Similarly, some Islamic interpretations suggest that hardship can be considered as Allah's test of Muslim's faith and “endurance of emotional suffering may be conceived as qualifying for religious blessing and reward" (El-Islam, 2004, p. 9). However, a recent study of Turkish poor consumers finds a negative relationship between faith and quality of life and suggests that, under the new logic of a religiously-inspired neoliberal political economy, the buffering potential of faith might have been diminished (Sand1kc1, Peterson, Ekici and Simkins, forthcoming). Thus, how and under what conditions religious belief and practice might operate as a coping mechanism against poverty requires further empirical investigations.

The role of communities in coping with poverty also offers research opportunities. For example, the notion of the solidarity economy might illuminate some particularities of how 
Muslim consumers deal with their impoverished conditions. The solidarity (or social) economy refers to the non-market oriented production and delivery of the means for survival of the poor and aims to fill the gap left by the public and private sectors (e.g., Moulaert and Ailenei, 2005). For example, a recent study of low-income practicing Muslim women in Iran documents the role these women play in mobilizing their community networks for poverty relief and mutual help (Bahramitash, 2014). The author finds that the female-dominated, mainly informal solidarity economy constitutes an important safety net in Iran; yet, it also reinforces social divisions and power structures in the society. Understanding how informal communities are mobilized in poor Muslim neighbourhoods and the gender and power dynamics characterizing these networks can provide new insights to organized and collective acts of coping discussed in the marketing literature.

Third, studies that investigate how different aspects of identity interact with each other and shape experiences of poverty are needed. In recent years, intersectionality has become a concept increasingly used in the social sciences to account for the interactivity of social identity structures in fostering experiences of privilege and oppression (e.g., Gopaldas, 2013; Saatcioglu and Corus, 2015). As in the case of poverty in general, in the context of Muslim poor consumers, vulnerability is likely to be shaped not only by economic deprivation but also by overlapping conditions that arise from various disadvantaged social positions. Among possible research avenues are the intersections of gender, ethnicity and poverty. Muslim societies are often characterized (and criticized for) their patriarchal nature (e.g., Kandiyoti, 1991). Scholars can examine how Islam and patriarchy interact and shape poor Muslim women's experiences in the domain of consumption and the nature and dynamics of women's struggle against oppressive conditions. Similarly, the intersections of ethnicity and poverty 
(and gender) can provide new insights to the marketplace experiences of vulnerability. Migration from poor Muslim countries to the Western world has been going on for a while. However, in recent years, with intensification of terrorism and wars in the Middle East, North Africa, and Southeast Asia, the number of refugees and migrants boosted (e.g., Norris and Inglehart, 2012). Studies exploring the interconnections between religion, ethnicity and socioeconomic deprivation are likely to uncover various dynamics shaping the marketplace experiences of poor Muslim migrants in Muslim-minority contexts and bring new insights into the literature on the intersectionality of poverty. Such perspective could also help illuminate possibly varying levels and types of coping (e.g., individual acts of survival and defiance as well as more collectively organized forms of coping) in Muslim contexts characterized by multiple interconnected forms of disadvantages.

\section{Islamic Charity, Power Dynamics, and Poverty Alleviation}

Religious organizations have always been involved in charity and poverty relief. However, there is increasing evidence that they have taken a distinctly moral and political character lately and become an important actor of aid and development (Bornstein and Redfield, 2011). Faith-based organizations seek to mobilize the religious in support of the poor and other disadvantaged groups, and fund programmes that tackle poverty and social exclusion. Recent studies show that faith-based organizations skilfully blend Islamic piety and neoliberal development and propagate an Islamic solution to social problems (Atia, 2011). Islamic aid organizations consist of civil society organizations, social welfare arms of Islamist political movements, transnational Islamic charities that raise funds across the diaspora, and corporate philanthropic organizations (Tadros, 2011). Research on each of these different types of faith organizations can further our understanding of the roles various market and non-market 
actors play in the social and discursive construction of poverty. How these organizations and their aid systems shape marketplace behaviour and consumption choices of the Muslim poor and if and how organized aid contributes to the marketplace empowerment of underprivileged Muslim consumers constitute important research avenues.

Critical consumer research attention is also needed to understand the marketplace dynamics and ramifications of zakat. While there is a consensus on the centrality of zakat as a vehicle of redistributive justice, critics argue that zakat and other Islamic forms of charity may, on the contrary, contribute to reinforcing the gap between the rich and the poor (Benthall, 1999; Farooq, 2008). As Kuran argues "on the one hand, [zakat] counsels the rich not to feel obligated to eradicate poverty and never to feel guilty for being well-off. On the other hand, [zakat] dampens the resentments of the poor and moderates their demands" (Kuran, 2003, pp. 283-4). Accordingly, how zakat is implicated in the class relations and reflected in the marketplace power dynamics represent interesting research questions. In a recent study of the changing meanings of zakat in Indonesia, Retsikas (2014) reports a shift in the emphasis from zakat as a right to zakat as philanthropic giving. Linking the change to the broader sociopolitical and economic developments, the author argues that "a new discourse on zakat arose as a result of a new wave of Islamic consciousness, serving both to underpin claims to distinction and to reinforce the legitimacy of the new wealth the middle class commanded" (p.364). More studies are needed to better understand how discourses around zakat and other forms of Islamic charities change over time and how these discourses shape experiences and expectations of the givers and recipients in different sociotemporal contexts. 
Finally, research on poor Muslim consumers can offer new insights into the microfinance literature. Microcredit facilities have shown to play an important role in helping the so-called "bottom-of-the -pyramid" in countries like Bangladesh. However, extremely poor Muslims seem to remain excluded from microfinance opportunities (Ali, 2014). While interest rate is often discussed as the reason for the Muslim poor's lack of interest in conventional microcredit programmes, research is needed to understand the emic and etic meanings and dynamics of microfinance in Muslim contexts. It is likely that, other than religious concerns, various sociocultural factors, such as gender dynamics and attitudes toward entrepreneurship, might contribute to the current lack of interest. On the other hand, scholars point out that Islamic banking organizations also remain rather uninterested in developing microfinance initiatives (Abdulrahman, 2007). Investigations of the institutional as well as market-related reasons of such lack can shed light on the potential of microcredit as a means for Muslim poor consumers' participation in the marketing system.

\section{Conclusion}

Poverty continues to be a pervasive problem in the majority of Muslim geographies. Despite the recent academic and managerial interest in Muslims as an attractive consumer segment, lack of basic resources, health deficiencies, and low quality of life characterize the everyday reality of a large population of Muslims around the world. Although socioeconomic justice and poverty eradication take a central place in Islamic teachings, current conditions of Muslims depict a rather troubling picture. We believe that marketing scholars are well equipped to offer new insights into the nature, dynamics, and implications of poverty and socioeconomic injustice in the Muslim contexts. 
The research agenda that we developed is far from exclusive and offers only a preliminary set of potential research areas. Critically-informed, interdisciplinary studies are likely to bring new insights and contribute to the current theorizations of poverty in the marketing field. Furthermore, these insights are likely to translate into policy recommendations and have the potential to make a real impact on the lives of poor Muslim consumers. In line with the recent emphasis within the marketing literature on a more pragmatic and inclusive approach to poverty, we hope that our chapter motivates interest within marketing and macromarketing scholars toward a better understanding of poverty and socioeconomic injustice in Muslim geographies.

\section{References}

Abdulrahman, A. (2007) 'Islamic Microfinance: A Missing Component in Islamic Banking', Kyoto of Islamic Area Studies, 1-2, pp. 38-53.

Adkins, N.R. and Ozanne, J.L. (2005) 'The Low Literate Consumer', Journal of Consumer Research, 32 (1), pp. 93-105.

Ahmad, K. and Hassan, A. (2000) 'Distributive Justice: The Islamic Perspective', Intellectual Discourse, 8(2), pp. 159-172.

Ahmad, W.M.W. and Mohamad, S. (2012) 'Classical Jurists' View on the Allocation of Zakat: Is Zakat Investment Allowed?', Middle-East Journal of Scientific Research, 12(2), pp. 195-203.

Al Khayyat, A.A. (1993) Zakat and its applications and profitable uses. Amman: Ministry of Awqaf and Islamic Affairs. 
Ali, A.E.E.S. (2014) 'Islamic Microfinance: Moving Beyond Financial Inclusion', Islamic Research and Training Institute, Working Paper 1435-11, Kingdom of the Saudi Arabia.

Alwitt, L.F. (1995) 'Marketing and the Poor', American Behavioral Scientist, 38(4), pp. 6477.

Alwitt, L.F. and Donley, T.D. (1996) The Low-Income Consumer: Adjusting the Balance of Exchange, Thousand Oaks, CA: Sage.

Andreasen, A.R. (1975) The Disadvantaged Consumer, New York, NY: The Free Press. Andreasen, A.R. (1993) 'Revisiting the Disadvantaged: Old Lessons and New Problems', Journal of Public Policy and Marketing, 12 (2), pp. 270-75.

Andreasen, A.R. (1997) 'From Ghetto Marketing to Social Marketing: Bringing Social Relevance to Mainstream Marketing', Journal of Public Policy and Marketing, 16(1), pp. 129-31.

Atia, M. (2012) “'A Way to Paradise’: Pious Neoliberalism, Islam, and Faith-based Development', Annals of the Association of American Geographers, 102(4), pp. 808827.

Bahramitash, R. (2014) 'Low-Income Islamic Women, Poverty and the Solidarity Economy in Iran', Middle East Critique, 23(3), pp. 363-377.

Benthall, J. (1999) 'Financial Worship: The Quranic Injunction to Almsgiving', The Journal of the Royal Anthropological Institute, 5(1), pp. 27-42.

Bertrand, M., Mullainathan, S., and Shafir, E. (2006) 'Behavioral economics and marketing in aid of decision making among the poor', Journal of Public Policy \& Marketing, 25(1), pp. 8-23. 
Blocker, C.P., Ruth, J.A., Sridharan, S., Beckwith, C., Ekici, A., Goudie-Hutton, M., Rosa, J.A., Saatcioglu, B., Talukdar, D., Trujillo, C. and Varman, R. (2011) 'Appling a Transformative Consumer Research Lens to Understanding and Alleviating Poverty', Journal of Research for Consumers, 19(1), pp. 1-9.

Blocker, C.P., Ruth, J.A., Sridharan, S., Beckwith, C., Ekici, A., Goudie-Hutton, M., Rosa, J.A., Saatcioglu, B., Talukdar, D., Trujillo, C. and Varman, R. (2013) 'Understanding Poverty and Promoting Poverty Alleviation through Transformative Consumer Research', Journal of Business Research, 66(8), pp. 1195-1202.

Bonner, M. (2005) 'Poverty and Economics in the Qur'an', The Journal of Interdisciplinary History, 35(3), pp. 391-406.

Bornstein, E. and Redfield, P. (eds.) (2011), Forces of Compassion: Humanitarianism between Ethics and Politics. Santa Fe, NM: SAR Press

Bradshaw, J. and Finch, N. (2003) 'Overlaps in Dimensions of Poverty', Journal of Social Policy, 32(4), pp. 513-25.

Chakravarti, D. (2006) 'Voices Unheard: The Psychology of Consumption in Poverty and Development', Journal of Consumer Psychology, 16(4), pp. 363-76.

Chapra, M.U. (2011) 'Islamic Economic Thought and the New Global Economy', Islamic Economic Studies, 9(1), pp. 2-16.

COMCEC (2014) 'Poverty Outlook 2014: Multidimensional Poverty', The Standing Committee for Economic and Commercial Cooperation of the Organization of the Islamic Cooperation [available at http://www.mod.gov.tr/Lists/RecentPublications/Attachments/66/COMCEC\%20Povert y\%20Outlook\%202014\%20-\%20Revised\%20Edition.pdf], (accessed February12, 2015). 
Crockett, D. and Wallendorf, M. (2004) 'The Role of Normative Political Ideology in Consumer Behavior', Journal of Consumer Research, 31(3), 511-28.

Dean, H. and Khan, Z. (1997) 'Muslim Perspectives on Welfare', Journal of Social Policy, 26(2), pp. 193-209.

FAO (2014) 'Low-Income Food-Deficit Countries (LIFDC): List for 2014', Food and Agriculture Organization of the United Nations, [available at http://www.fao.org/countryprofiles/lifdc/en/], accessed February 12, 2015.

Farooq, M.O. (2008) 'The Challenge of Poverty and the Poverty of Islamic Economics', Journal of Islamic Economics, Banking and Finance, 4(2), pp. 35-58. Foucault, M. (1978) The History of Sexuality. New York, NY: Vintage.

Gauthier, F., Martikainen, T. and Woodhead, L. (2013) 'Acknowledging a Global Shift: A Primer for Thinking about Religion in Consumer Societies', Implicit Religion, 16(3), pp. 261-276.

Gaventa, J. (1980) Power and Powerlessness: Quiescence and Rebellion in an Appalachian Valley. Chicago, IL: University of Illinois Press.

Gebauer, J.E., Nehrlich, A.D., Sedikides, C., and Neberich, W. (2012) 'The Psychological Benefits of Income are Contingent on Individual-level and Culture-level Religiosity', Social Psychological and Personality Science, 4(5), pp. 569-578.

Gilliat, S. (2001) How the Poor Adapt to Poverty in Capitalism. New York, NY: Edwin Mellen Press.

Gilliom, J. (2001) Overseers of the Poor: Surveillance, Resistance, and the Limits of Privacy. Chicago, IL: The University of Chicago Press.

Gopaldas, A. (2013) 'Intersectionality 101', Journal of Public Policy \&Marketing, 32 (special issue), pp. 90-94. 
Guner, O. (2005) 'Poverty in Traditional Islamic Thought: Is it Virtue or Captivity?', Studies in Islam and the Middle East Journal, 2(1), pp. 1-12.

Hackney, C.H. and Sanders, G.H. (2003) 'Religiosity and Mental Health: A meta-Analysis of Recent Studies', Journal for the Scientific Study of Religion,42(1), pp. 43-55.

Hill, R.P. (1991) 'Homeless Women, Special Possessions, and the Meaning of Home: An Ethnographic Case Study', Journal of Consumer Research, 18(3), pp. 298-310.

Hill, R.P. (2001) 'Surviving in a Material World', Journal of Contemporary Ethnography, 30(4), pp. 364-91.

Hill, R.P. (2002) 'Compassionate Love, Apage, and Altruism: A New Framework for Understanding and Supporting Impoverished Consumers', Journal of Macromarketing, 22(1), pp. 19-31.

Hill, R.P. and Stamey, M. (1990) 'The Homeless in America: An Examination of Possessions and Consumption Behaviors', Journal of Consumer Research, 17(3), pp. 303-21.

Izberk-Bilgin, E. (2012) 'Infidel Brands: Unveiling Alternative Meanings of Global Brands at the Nexus of Globalization, Consumer culture, and Islamism', Journal of Consumer Research, 39(4), pp. 663-687.

Jafari, A. (2012) 'Islamic Marketing: Insights from a Critical Perspective', Journal of Islamic Marketing, 3(1), pp. 22-34.

Jafari, A. and Süerdem, A. (2012) 'An Analysis of Material Consumption Culture in the Muslim World', Marketing Theory, 12(1), pp. 59-77.

Jafari, A. and Sandıkcı, O. (2015) '“Islamic' Consumers, Markets, and Marketing: A critique of El-Bassiouny’s (2014) ‘The One-billion-plus Marginalization', Journal of Business Research, http://dx.doi.org/10.1016/j.jbusres.2015.04.003. 
Jennings, J. (1999) 'Persistent Poverty in the United States: Review of Theories and Explanations', in Kushnick, L. and Jennings, J. (eds.) A New Introduction to Poverty: The Role of Race, Power, and Politics, New York, NY: New York University Press, pp. $13-38$.

Jones, C. and Novak, T. (1999) Poverty, Welfare and the Disciplinary State, New York, NY: London.

Jordan, B. (1996) A Theory of Poverty and Social Exclusion, Cambridge, MA: Polity Press. Joshanloo, M. and Weijers, D. (2015) 'Religiosity Reduces the Negative Influence of Injustice on Subjective Well-being: A Study in 121 Nations', Applied Research in Quality of Life, DOI:10.1007/s11482-014-9384-5.

Kandiyoti, D. (1991) 'Islam and Patriarchy: A Comparative Perspective', in Keddie, N.R and Baron, B. (eds.) Women in Middle Eastern History: Shifting Boundaries in Sex and Gender, New Haven, CT: Yale University Press, pp. 23-42.

Khan, M.A. (1989) 'Islamic Economics: The State of the Art', in Ghazali, A. and Syed Agil, S.M. (eds.) Readings in the Concept and Methodology of Islamic Economics, Malaysia: Pelanduk Publications, pp. 120-40.

Kroessin M.R. (2011) 'A Genealogy of the Islamic Development Discourse: Underlying Assumptions and Policy Implications from a Development Studies Perspective', 8th International Conference on Islamic Economics and Finance [available athttp://citeseerx.ist.psu.edu/viewdoc/download?doi=10.1.1.461.7255\&rep=rep1\&type $=$ pdf], accessed March 26, 2015.

Kuran, T. (2003) 'Islamic Redistribution through Zakat: Historical Record and Modern Realities', in M. D. Bonner, M. Ener and A. Singer (eds.), Poverty and Charity in Middle Eastern Contexts, Albany: State University of New York Press, pp. 275-293. 
Kuran, T. (1997) 'Islam and Underdevelopment: An Old Puzzle Revisited', Journal of Institutional and Theoretical Economics, 153(1), pp. 41-71.

Kuran, T. (1989) 'On the Notion of Economic Justice in Contemporary Islamic Thought', International Journal of Middle East Studies, 21(2), pp. 171-90.

Levitas, R. (1998) The Inclusive Society? Basingstoke: Macmillan.

Lewis, O. (1959) Five Families: Mexican Case Studies in the Culture of Poverty, New York, NY: Basic Books.

Lewis, O. (1970) Anthropological Essays, New York, NY: Random House.

Lister, R. (2004) Poverty, Malden, MA: Polity Press.

Luce, S. (2004) Fighting for a Living Wage, Ithaca, NY: Cornell University Press.

Metwally, M.M. (1997) 'Economic Consequences of Applying Islamic Principles in Muslim Societies', International Journal of Social Economics, 24(7/8/9), pp. 941-957.

Mick, D.G., Pettigrew, S., Pechmann, C., and Ozanne, J. (2011) 'Origins, Qualities, and Envisionments of Transformative Consumer Research', in Mick, D.G., Pettigrew, S., Pechmann, C., and Ozanne, J. (eds.) Transformative Consumer Research for Personal and Collective Well-Being, New York, NY: Routledge, pp. 3-24.

Miller, C.T. and Kaiser, C.R. (2001) 'A Theoretical Perspective on Coping with Stigma', Journal of Social Issues, 57(1), pp. 73-92.

Moulaert, F. and Ailenei, O. (2005) 'Economy, Third Sector and Solidarity Relations: A Conceptual Synthesis from History to Present', Urban Studies, 42(11), pp. 2037-2053.

Murray, J.B. and Ozanne, J.L. (2006) 'Rethinking the Critical Imagination', in Belk, R.W. (ed.) Handbook of Qualitative Research Methods in Marketing, Northampton, MA: Edward Elgar, pp. 46-55. 
Narayan, D., Chambers, R., Shah, M.K. and Petesch, P. (2000) Voices of the Poor: Crying Out for Change, Washington, DC: World Bank.

Newman, K.S. (2007) No Shame in My Game: The Working Poor in the Inner City, New York, NY: Vintage Books.

Newman, K.S. and Chen, V.T. (2007) The Missing Class: Portraits of the Near Poor in America, Boston, MA: Beacon Press.

Nienhaus, V. (2006) 'Zakat, Taxes, and Public Finance in Islam', in Behdad, S. and Nomani, F. (eds.), Islam and the Everyday World - Public Policy Dilemmas, Abingdon and New York: Routledge, pp. 165-192.

Norris, P. and Inglehart, R. (2012) 'Muslim Integration into Western Cultures: Between Origins and Destinations', Political Studies, 60(2), pp. 228-251.

O’Brien, D., Wilkes, J., de Haan, A., and Maxwell, S. (2009) 'Poverty and Social Exclusion in North and South', IDS Working Paper 55, Institute of Development Studies and Poverty Research Unit, University of Sussex.

O’Connor, A. (2001) Poverty Knowledge, Princeton, NJ: Princeton University Press.

Ozanne, J.L. and Saatcioglu, B. (2008) 'Participatory Action Research', Journal of Consumer Research, 35(3), pp. 423-39.

Ozanne, J.L. and Anderson, L. (2010) 'Community Action Research', Journal of Public Policy and Marketing, 29 (1), pp. 123-137.

Okte, K.S. (2010) 'Fundamentals of Islamic Economy and Finance: Theory and Practice’, Electronic Journal of Social Sciences, 9(31), pp. 180-208.

Paules, G.F. (1991) Dishing It Out: Power and Resistance among Waitresses in a New Jersey Restaurant. Philadelphia, PA: Temple University Press. 
Prahalad, C.K. and Hammond, A. (2002) 'Serving the World's Poor, Profitably', Harvard Business Review, 80 (9), pp. 48-59.

Qardawi, Y. (1999) Fiqhaz-Zakat: A Comparative Study, London: Dar-al-Taqwa.

Rank, M.R. (2004) One Nation, Underprivileged, New York, NY: Oxford University Press.

Retsikas, K. (2014) 'Reconceptualising Zakat in Indonesia', Indonesia and the Malay World, 42(124), pp. 337-357.

Room, G.J. (1999) 'Social Exclusion, Solidarity and the Challenge of Globalization', International Journal of Social Welfare, 8 (1999), pp. 166-74.

Saatcioglu, B. and Corus, C. (2014) 'Poverty and Intersectionality A Multidimensional Look into the Lives of the Impoverished', Journal of Macromarketing, 34(2), pp. 122-132.

Saatcioglu, B. and Ozanne, J.L. (2013) 'Moral Habitus and Status Negotiation in a Marginalized Working-Class Neighborhood', Journal of Consumer Research, 40 (3), pp. 692-710.

Sadeq, A.M. (1997) 'Poverty Alleviation: An Islamic Perspective', Humanomics, 13(3), pp. 110-134.

Sand1kc1, O. (2011) 'Researching Islamic Marketing: Past and Future Perspectives', Journal of Islamic Marketing, 2(3), pp. 246-258.

Sand1kc1, O., Peterson, M., Ekici, A., and Simkins, T. (forthcoming), "Development and Quality of Life in Turkey: How Globalization, Religion, and Economic Growth Influence Individual Well-being," Journal of Macromarketing.

Santos, N.J.C. and Laczniak, G.R. (2009) 'Marketing to the Poor: An Integrative Justice Model for Engaging Impoverished Market Segments', Journal of Public Policy and Marketing, 28 (1), pp. 3-15.

Scott, J.C. (1985) Weapons of the Weak, New Haven, CT: Yale University Press. 
Scott, J.C. (1990) Domination and the Arts of Resistance, New Haven, CT: Yale University Press.

Sen, A. (1999) Development as Freedom, New York, NY: Alfred A. Knopf, Inc.

Sen, A. (2000) 'Social Exclusion: Concept, Application, and Scrutiny', Social Development Papers No. 1, Office of Environmental and Social Development, Asian Development Bank. SESRIC (2013) 'Education and Scientific Development in the OIC member countries 2012/2013," Statistical, Economic and Social Research and Training Centre for Islamic Countries, Ankara, Turkey, [available at http://www.sesrtcic.org/files/article/458.pdf], accessed May 6, 2010.

SESRIC (2012) 'Annual Economic Report on the OIC Countries 2012', Statistical, Economic and Social Research and Training Centre for Islamic Countries, Ankara, Turkey, [available at http://www.sesrtcic.org/files/ article/454.pdf], accessed May 6, 2010. Shipler, D.K. (2004) The Working Poor: Invisible in America, New York, NY: Knopf. Tadros, M. (2011) 'Islamic Philanthropy and Wellbeing', The Bellagio Initiative, November. Talukdar, D., Gulyani, S. and Salmen, L.F. (2005) 'Customer Orientation in the Context of Development Projects: Insights from the World Bank', Journal of Public Policy and Marketing, 24 (1), pp. 100-11.

Townsend, P. (1993) The International Analysis of Poverty, Hemel Hempstead: Harvester Wheatsheaf.

UlHaq, I. (1996) Economic Doctrines of Islam, Herndon, VA; International Institute of Islamic Thought.

UNDP (2014) 'Human Development Report 2014,' United Nations Development Program, [available at http://hdr.undp.org/sites/default/files/hdr14-report-en-1.pdf], accessed May 18, 2015. 
Ustuner, T. and Holt, D.L. (2007) 'Dominated Consumer Accculturation: The Social Construction of Poor Migrant Women's Consumer Identity Projects in a Turkish Squatter', Journal of Consumer Research, 34 (1), pp. 41-56.

Viswanathan, M. and Rosa, J.A. (2007) 'Product and Market Development for Subsistence Marketplaces: Consumption and Entrepreneurship beyond Literacy and Resource Barriers', in Cheng, J.L.C. and M.A. Hitt (eds.) Advances in International Management, Oxford: Elsevier, pp. 1-17.

Viswanathan, M. and Rosa, J.A. (2010) 'Understanding Subsistence Marketplaces: Toward Sustainable Consumption and Commerce for a Better World', Journal of Business Research, 63 (6), pp. 535-37.

Viswanathan, M., Rosa, J.A., and Ruth, J.A. (2010) 'Relationships and Commitment as Cornerstones in Marketing Systems: Subsistence Consumer-Merchants in Chennai, India', Journal of Marketing, 74 (1), pp. 1-17.

Viswanathan, M., Sridharan, S., and Ritchie, R. (2010) 'Understanding Consumption and Entrepreneurship in Subsistence Marketplaces', Journal of Business Research, 63(6), pp. 570-581.

Waxman, C. I. (1983) The Stigma of Poverty: A Critique of Poverty Theories and Policies, New York, NY: Pergamon Press.

Wilson, E.K. and Steger, M.B. (2013) Religious Globalisms in the Post-secular Age', Globalizations, 10(3), pp. 481-495.

The World Bank (2000) World Development Report 2000/2001: Attacking Poverty, Washington, DC: The World Bank. 